\title{
SLC28A1 Gene
}

National Cancer Institute

\section{Source}

National Cancer Institute. SLC28A1 Gene. NCI Thesaurus. Code C96049.

This gene is involved in nucleotide transport. 